\title{
Production and Quality of Murdannia bracteata Biomass as Impact of Magnesium Foliar Fertilizer
}

\author{
Rahmawati T, Abdullah L, Prihantoro I \\ Faculty of Animal Husbandry, Bogor Agricultural University \\ E-mail: tentirahmawati10@gmail.com \\ (received 06-07-2015; revised 12-08-2015; accepted 25-09-2015)
}

\begin{abstract}
ABSTRAK
Rahmawati T, Abdullah L, Prihantoro I. 2015. Produksi dan kualitas biomassa Murdannia bracteata sebagai dampak aplikasi pupuk daun magnesium. JITV 20(3): 207-213. DOI: http://dx.doi.org/10.14334/jitv.v20i3.1188

Murdannia bracteata adalah salah satu hijauan pakan yang berpotensi sebagai pakan ternak ruminansia dan belum banyak diteliti. Hijauan ini mengandung mineral yang tinggi dan berpotensi sebagai pakan fungsional. Tujuan dari penelitian ini adalah untuk mengevaluasi pertumbuhan, produktivias serta kadar klorofil dan mineral Murdannia bracteata yang dipupuk dengan pupuk daun magnesium. Penelitian ini menggunakan rancangan acak lengkap dengan 5 perlakuan dan 4 ulangan. Perlakuan dosis magnesium yang diberikan adalah 0 ppm, 2000 ppm, 4000 ppm, 8000 ppm, 12000 ppm. Penelitian dilakukan di rumah kaca laboratorium lapang agrostologi, Fakultas Peternakan, IPB. Hasil penelitian menunjukkan bahwa penambahan dosis pupuk magnesium tidak memberikan pengaruh yang nyata $(\mathrm{P}>0,05)$. terhadap pertumbuhan, produktivitas, dan kadar klorofil. Peningkatan dosis magnesium menyebabkan turunnya kadar kalsium, kalium, dan zink $(\mathrm{P}<0,05)$, namun tidak pada phosphor dan natrium $(\mathrm{P}>0,05)$. Kesimpulannya, pemberian pupuk daun magnesium hingga dosis 12000 ppm tidak memberikan respon negatif terhadap pertumbuhan, produktivitas, serta kualitas tanaman. Peningkatan dosis pupuk magnesium mengakibatkan penurunan beberapa kandungan mineral dalam tanaman, khususnya kalsium, kalium dan zink.
\end{abstract}

Kata Kunci: Murdannia bracteata, Magnesium, Produktivitas, Kualitas

\section{ABSTRACT}

Rahmawati T, Abdullah L, Prihantoro I. 2015. Production and quality of Murdannia bracteata biomass as impact of magnesium foliar fertilizer. JITV 20(3): 207-213. DOI: http://dx.doi.org/10.14334/jitv.v20i3.1188

\begin{abstract}
Murdannia bracteata is one of potential forages for ruminant that has not been studied yet. This forage contents high mineral and it can be as fungtional feed. The aim of this study was to evaluate the growth and productivity, chlorophyll and minerals content of Murdannia bracteata caused by magnesium foliar application. The experiment was arranged in randomized complete design with five treatments and 4 replications. The application of magnesium level was arranged into: 0 ppm, 2000 ppm, 4000 ppm, 8000 ppm, and 12000 ppm. The study was conducted in a greenhouse, field laboratory of Agrostology, Faculty of Animal Science, Bogor Agricultural University. The result showed that growth, productivity, and chlorophyll content were not significantly $(\mathrm{P}>0.05)$ affected by increasing magnesium level. Increasing magnesium dossage resulted in decreasing calsium, potassium, and zink content $(\mathrm{P}<0.05)$, but not on phosphor and sodium $(\mathrm{P}>0.05)$. In conclusion, increasing magnesium dossage up to 12000 ppm did not significantly affect growth, productivity, and chlorophyll content. However, increasing magnesium level decreased calsium, potassium, and zink content.
\end{abstract}

Key Words: Murdannia bracteata, Magnesium, Productivity, Quality

\section{INTRODUCTION}

Murdannia bracteata is one of forage has not been widely studied. This potential forage as ruminant's functional feed included into class Commelinales, family Commelinanceae, genus Murdannia and species M. bracteata (C.B. Clarke) Kuntze ex D.Y. It has advantage as crude fiber source may be used as antiinflamatory and high mineral content (Wang et al. 2007, Rahmawati 2014). Administration of organic fertilizer by 10 ton ha ${ }^{-1}$ and $37 \%$ shading affect the height of level of calcium (Ca), magnesium (Mg), calium (K), and zink (Zn). Content of those $\mathrm{Ca}, \mathrm{Mg}, \mathrm{K}$, and $\mathrm{Zn}$ is
16847 ppm, 4566 ppm, 29323 ppm, dan 44 ppm, respectively.

Those minerals content were higher compared to other forages such as Brachiaria humidicola and Indigofera sp. Minerals contained in this forage is potentian as organic magencium source for animal.

Magnesium (Mg) is macro mineral needed by ruminants. $\mathrm{Mg}$ is mineral which is closely related to calcium. About $70 \%$ magnesium is found in bone. This mineral plays a role as enzyme activator and key of cellular biochemist process (McDonald et al. 2010). Administration of $10 \% \mathrm{DM}$ of $M$. bracteata as magnesium source in beef cattle's diet may increase 
VFA production, DM and organic material digestibility, and microbe protein synthesis (Rais 2015).

Magnesium has important role for the crop, among other as the main element of chlorophyll forming, playing role in crop metabolism such as photosynthesis and charbohydrate forming (Gerendàs \& Führs 2013), playing role in nitrogen metabolism, enzyme activator, and nucleate acid synthesis (Salama et al. 2014). Magnesium deficiency in crop was characterized by chlorosis between the leaf bone, but the leaf was still green (Chalimah \& Sulaiman 2015). Therefore, magnesium must be available in sufficient number. The main source of mineral on crops is origine from soil. There are several soils with low nutrient content, such as darmaga latosol soil. Magnesium content in the darmaga latosol soil was only $0.06 \%$ (Utami 2015). Therefore, it needed magnesium fertilization. Magnesium fertilization was given by several ways. One of those ways is through the leave known as foliar fertilization. Foliar fertilization is fertilizer diluted by water and sprayed on the leaves (Hanadyo et al. 2013). That liquid fertilizer entered the leaves by penetration process to cuticle tissue through stomata pathway (Aghtape et al. 2011). This fertilizer has advantage. Nutrient given directly may be absorbed through the stomata pathway. Sprayed fertilizing should not in large amount.

The $M$. bracteata has high magnesium content. In this study, administration of foliar fertilizer was carried out to determine capability of that $M$. bacterata in increasing magnesium content without disturbing the growth, productivity, and its quality planted on lasotol dramaga soil.

\section{MATERIALS AND METHODS}

This research was carried out in a greenhouse of Field Laboratorium of Agrostology, Laboratorium of Animal Nutrition, Faculty of Animal Science, Bogor Agriculture University. Study was carried out for 4 months started from Februari 2015 until Mei 2015. It consisted of planting the Murdannia bracteata in polybag and measurement of chlorophyll and several minerals level.

Equipments used in this study were digital weigher scale 1 gram, gauge, polybag with diameter $40 \mathrm{~cm}$, oven $60^{\circ} \mathrm{C}$ Swallow LTE.Scientific LTF K11755, oven $105^{\circ} \mathrm{C}$, and minerals analizing tools. Materials used was seed of Murdannia braceata, organic fertilizer 10 ton/ha (commercial fertilizer), lime, $\mathrm{MgSO}_{4} \cdot 7 \mathrm{H}_{2} \mathrm{O}$, commercial NPK and latosol dramaga soil.

The Murdannia bracteata was maintained for 2 months fertilized everyweek started in third week. Fertilization was done by spraying 2-3 ml magnesium liquid. Administration of organic fertilizer lime, and NPK was done once at the beginning of planting.
Watering and pest weeding were done everyday. The Murdannia bracteata was harvested after 8 weeks with sparating stems, leaves, roots, and flowers for weighing. Sampels were putted into oven $60^{\circ} \mathrm{C}$, oven $105^{\circ} \mathrm{C}$, and furnace to determine level of dry and organic materials. One leaf in every experimental unit was sparated to be anallized its chlorophyll content. Those leaf samples were taken randomly from every crop. Samples preparation was done referring to method of Sims \& Gamon (2002) and it was then seen its absorbance using spectrophotometer with wave length by 537, 663, 647 nm.

\begin{tabular}{|c|c|}
\hline Anthocyanin & $\begin{aligned}= & 0.08173 * \mathrm{~A} 537-0.00697 * \mathrm{~A} 647- \\
& 0.002228 * \mathrm{~A} 663\end{aligned}$ \\
\hline $\begin{array}{l}\text { Chlorophyll a } \\
\text { (Chl a) }\end{array}$ & $\begin{aligned}= & 0.01373 * \mathrm{~A} 663-0.00089 * \mathrm{~A} 537- \\
& 0.003046 * \mathrm{~A} 647\end{aligned}$ \\
\hline $\begin{array}{l}\text { Chlorophyll b } \\
\text { (Chl b) }\end{array}$ & $\begin{aligned}= & 0.02405 * \mathrm{~A} 647-0.004305 * \mathrm{~A} 537- \\
& 0,005507 * \mathrm{~A} 663\end{aligned}$ \\
\hline Caroten & $=\frac{(A 470-(17.1 *(\text { Chl } a+C h l b)-9.479 * \text { antosianin }))}{119.26}$ \\
\hline
\end{tabular}

Total Chorophyll $=C h l a+C h l b$

Every experimental unit of leaf samples which have been analized for organic materials was analized content of $\mathrm{Ca}, \mathrm{P}, \mathrm{Mg}, \mathrm{K}, \mathrm{Na}$ and $\mathrm{Zn}$ using wet incorporation method Reitz et al. (1960). Concentration of those minerals level were measured using atom absorption spectrophotometer (AAS), and the mineral $\mathrm{P}$ was measured using spectrophotometer (UV Visible) with wavelengath by $660 \mathrm{~nm}$.

Levels of magnesium given were 0 ppm, 2000 ppm, 4000 ppm, 8000 ppm, and 12000 ppm. This study was used completely randomized design with 5 treatments and 4 replications. Data obtained were tested by Analysis of Variance (ANOVA) using SPSS 16 software. If there was a significant difference, orthogonal polynomial was done (Matjik \& Sumertajaya 2006).

\section{RESULT AND DISCUSSION}

\section{Murdannia bracteata growth}

Plant growth consists of 2 phases, namely vegetative and generative phase. Vegetative phase consist of development of root, leaf, and stem. Generative phase is a reproductive phase consisting of forming and development of flower and bud. Plant growth is metabolic result of life cells requiring carbohydrate and may be measured quantitatively. The Murdannia bracteata growth by adding magneciun in different level was presented in Table 1 and 2. 
Rahmawati et al. Production and quality of Murdannia bracteata biomass as impact of magnesium foliar fertilizer

Administration of magnesium foliar fertilizer with different level did not significantly $(\mathrm{P}>0.05)$ affect the vegetative growth of Murdannia bracteata. Administration of magnesium foliar fertilizer up to 12000 ppm showed the same vegetative growth effect to the control.

This shows that administration of magnesium in that level did not affect the Murdannia bracteata growth. Growth disruption due to toxicity of magnesium was marked by disruption increase of plant height growth and leaf wide growth due to an antagonism between the magnesium and calcium (Fitriyatno et al. 2012). Leaf wide did not response significantly. This showed that the leaf may do good photosynthesis unmolested by administration of magnesium foliar fertilizer.

Administration of magnesium foliar fertilizer with different level did not significantly $(\mathrm{P}>0.05)$ affect generative growth of the Murdiannia bracteata. Administration of that fertilizer in 12000 ppm did not affect generative growth of the Murdiannia bracteata. This shows that the magnesium foliar fertilizer administration up to that level may still be tolerated by the $M$. bracteata. Crops that are less tolerant will show negative response, such as decrease of generative growth with increase of magnesium level. However, toxicity of magnesium in crops is rarely happening. Excess of magnesium in crops will be squestered in vacuola (Tang et al. 2015).

\section{Productivity of Murdannia bracteata}

Productivity of the Murdannia bracteata was divided into fresh weight and dry weight. Fresh weight and dry weight are one of growth indicators of crop. Dry weight is an indicator of the number of organic material successfully synthesized by crops from anorganic matterials.

Average fresh and dry weight of the Murdannia bracteata were presented in Table 3. Administration of magnesium foliar fertilizer in different level did not significantly $(\mathrm{P}>0.05)$ affect biomass production, and vegetative and generative growth rate of the $M$. bracteata, so that productivity of the $M$. bracteata was also not significantly different. Crops that are not tolerant to magnesium stress will show negative response, such as decrease of its produvtivity because of disruption of carbohydrate metabolism due to decrease of $\mathrm{Zn}$ content in the crops.

Increase of magnesium content in crops may decrease Zn content and then preventing carbonic anhydrase enzyme, so that the carbohydrate is concentred in the crown (Barker \& Eaton 2015). Nonedible fresh and dry weight in this study was not affected by magnesium fertilizing. This shows that carbohydrate metabolism in this crop was not disturbed by high of magnesium foliar fertilizer level administered. Carbohydrate metabolism in the root and

Table 1. Vegetative growth of $M$. bracteata as an impact of magnesium foliar fertilizer administration in different level

\begin{tabular}{|c|c|c|c|}
\hline $\begin{array}{l}\text { Level of magnesium } \\
(\mathrm{ppm})\end{array}$ & $\begin{array}{l}\text { Increase of crop length } \\
\text { (cm/week) }\end{array}$ & $\begin{array}{l}\text { Increase of the number of leaves } \\
\text { (cm/week) }\end{array}$ & $\begin{array}{l}\text { Wide of leaves } \\
\quad(\mathrm{cm})\end{array}$ \\
\hline 0 & $2.72 \pm 0.49$ & $16.56 \pm 2.61$ & $1.89 \pm 0.10$ \\
\hline 2000 & $3.30 \pm 0.39$ & $19.09 \pm 2.84$ & $1.98 \pm 0.10$ \\
\hline 4000 & $3.05 \pm 0.34$ & $20.79 \pm 3.43$ & $1.95 \pm 0.08$ \\
\hline 8000 & $2.87 \pm 0.38$ & $19.31 \pm 4.12$ & $1.94 \pm 0.05$ \\
\hline 12000 & $3.01 \pm 0.15$ & $22.19 \pm 2.01$ & $1.97 \pm 0.07$ \\
\hline
\end{tabular}

Table 2. Generative growth of $M$. bracteata as an impact of magnesium foliar fertilizer administration in different level

\begin{tabular}{lccc}
\hline \hline Level of magnesium $(\mathrm{ppm})$ & $\begin{array}{c}\text { Increase of the number of flower } \\
(\mathrm{cm} / \text { week })\end{array}$ & $\begin{array}{c}\text { Increase of the number of bud } \\
(\mathrm{cm} / \text { week })\end{array}$ & $\begin{array}{c}\text { Stolon length } \\
(\mathrm{cm})\end{array}$ \\
\hline 0 & $3.25 \pm 2.85$ & $2.72 \pm 0.62$ & $66.88 \pm 37.72$ \\
2000 & $5.38 \pm 2.02$ & $2.66 \pm 0.48$ & $88.00 \pm 22.38$ \\
4000 & $4.97 \pm 2.62$ & $3.44 \pm 0.24$ & $71.00 \pm 2.83$ \\
8000 & $2.88 \pm 0.47$ & $2.94 \pm 1.04$ & $89.13 \pm 9.78$ \\
12000 & $2.97 \pm 0.41$ & $3.84 \pm 0.90$ & $108.38 \pm 29.16$ \\
\hline
\end{tabular}


crown was running normally. Inhibition of the carbohydrate metabolism will disrupt metabolism of crop cells, decreasing crop growth, and then will affect the productivity. This is suspected due to administration of organic fertilizer as basic fertilizer by 10 ton ha $^{-1}$ in this study has fulfilled nutrient balance required by the crop. Organic fertilizer has an important role in improving physical, chemical, and biological characteristics of soil, so that it may increase land productivity and fertilizer efficiency (Supartha et al 2012). In a provious study, administration of organic fertilizer by 10 ton ha-1 showed the best productivity of the $M$. bracteata (Rahmawati 2014). Table 3 shows that decrease pattern of dry matter. By administration of magnesium fertilizer up to $8000 \mathrm{ppm}$, the crop was still able to maintain dry weight by $11-12 \%$, but in administration of magnesium fertilizer decreased the dry weight into $8 \%$. Administration of magnesium fertilizer up to $12000 \mathrm{ppm}$ increased magnesium content in crop and was suspected increasing water content level. Magnesium is an ion that has 2 cations. Those cations have high affinity to various ligands and are surrounded by 2 water moleculs, namely: inner layer and outer layer. The inner layer consists of 6 water moleculs forming magnesium complex in the form of octahedral [Mg(H2O)6] 2+. Outer layer consists of 12 water moleculs (Grzebisz 2015).

\section{Quality of Murdannia bracteata}

Quality of $M$. braceata based on mineral content, mineral absorbtion, and chlorophyll influenced by administration of magnesium in different level was presented in Figure 1, Table 4, and Table 5. Analysis of variance result of mineral content of the $M$. bracteata with magnesium administration in different level showed significant $(\mathrm{P}<0.05)$ result to $\mathrm{Ca}, \mathrm{Mg}, \mathrm{K}$, and $\mathrm{Zn}$, but it was no significant $(\mathrm{P}>0.05)$ effect to $\mathrm{P}$ and $\mathrm{Na}$. Increasing level of magnesium affected increase of $\mathrm{Mg}$ and decrease $\mathrm{Ca}, \mathrm{C}$, and $\mathrm{Zn}$. This shows that spraying of foliar fertilizer given direct effect against nutrient content. Fertilizing through leaves is one of alternatives fertilizing has quicker reaction and more efficient with the relatively few use of fertilizer (Portu et al. 2015).

Mineral has synergic and antagonic characteristics between one and others. Increasing of one mineral in crops will decrease the other minerals content. Addition of magnesium will increase magnesium content and decreasing $\mathrm{Ca}, \mathrm{K}$, and $\mathrm{Zn}$. This shows that magnesium sprayed through leaves was penetred into leaves, so that may increase magnesium content and decreasing the other minerals content (Figure 1). In the same figure, it is also showed that there is about the same antagonistic pattern between $\mathrm{Mg}$, $\mathrm{K}$, and $\mathrm{Zn}$. The two graphycs show that in spraying of foliar leave in 2000 and 4000 ppm there was magnesium saturation, so that in those two levels, magnesium level is not different. This caused content of $\mathrm{K}$ and $\mathrm{Zn}$ in those levels did not significantly decrease. The same thing was in spraying in 8000 and 12000 ppm.

Mineral in crop is absorbed in the form of ion. High concentration of magnesium may cause deficiency of other substantial cations. Magnesium toxicity symptom was highly related to decrease of $\mathrm{Ca}$ and $\mathrm{K}$ content (Merhaut 2007). However it showed toxicity symptom, the growth and productivity of the $M$. bracteata did not show negative response. Crop may maintain anioncation balance if it is added by some minerals expect kalium (Mengel 2007). This shows that addition of $\mathrm{Mg}^{2+}$ to crop replaces other cations. It causes decrease of cation content of calcium, kalium, and zinc. Magnesium spraying to crop increased magnesium content. High magnesium content out of cell caused stress censor of magnesium in the active plasm membrane. Stress censor of the magnesium is calcineurin B-like (CBL) 2 and 3. CBL-2 and CBL-3 will interact with calcineurin protein kinase (CPIK) to manage magnesium absorption into vacuola. There are other censors around the vacuola, such as CBL-10 for

Table 3. Production of fresh and dry biomass of $M$. bracteata based on level of magnesium fertilizing

\begin{tabular}{lcccc}
\hline \hline \multirow{2}{*}{$\begin{array}{l}\text { Level of magnesium } \\
(\mathrm{ppm})\end{array}$} & Edible & Non-edible & Edible & Dry weight (g) \\
\cline { 2 - 5 } & $136.5 \pm 34.7$ & $32.6 \pm 16.6$ & $14.2 \pm 6.8$ & Non-edible \\
\hline 0 & $142.3 \pm 26.3$ & $35.1 \pm 11.5$ & $13.23 \pm 8.7$ & $8.7 \pm 3.1$ \\
2000 & $161.1 \pm 30.8$ & $46.5 \pm 16.6$ & $16.5 \pm 7.0$ & $5.4 \pm 3.7$ \\
4000 & $120.3 \pm 30.4$ & $27.4 \pm 16.7$ & $13.1 \pm 1.2$ & $4.1 \pm 3.9$ \\
8000 & $158.1 \pm 13.8$ & $43.0 \pm 12.8$ & $9.9 \pm 1.7$ & $5.8 \pm 4.1$ \\
12000 & & & & \\
\hline
\end{tabular}


Rahmawati et al. Production and quality of Murdannia bracteata biomass as impact of magnesium foliar fertilizer

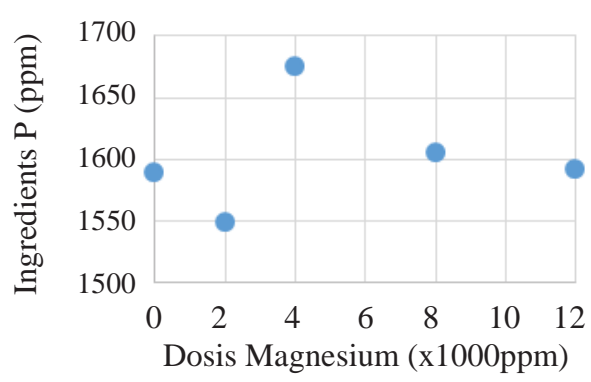

Figure 1a

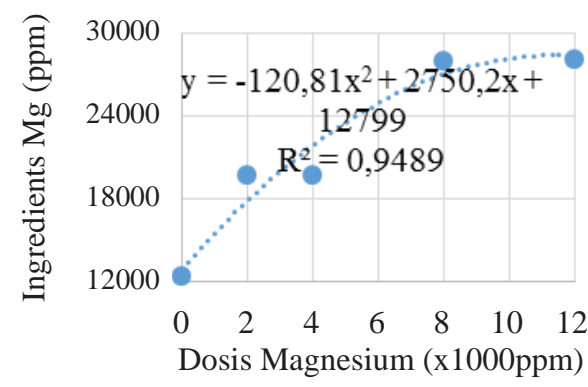

Figure 1c

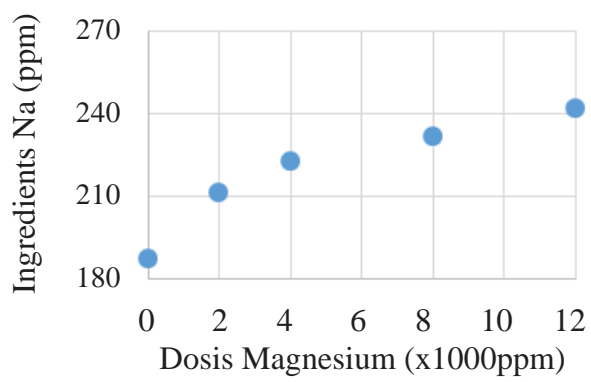

Figure 1e

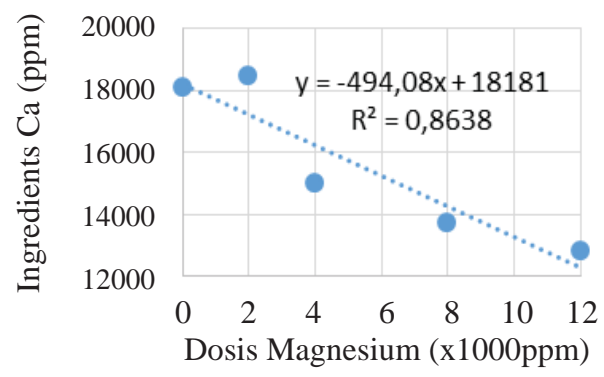

Figure $1 b$

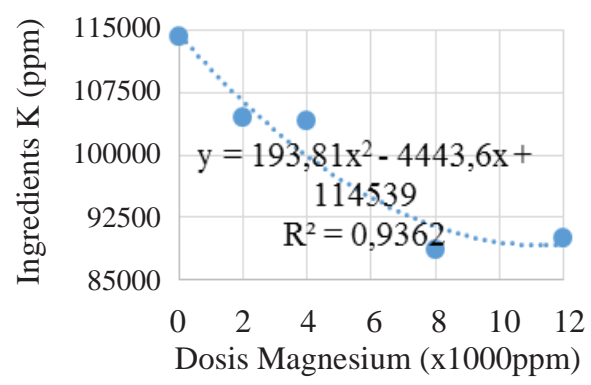

Figure 1d

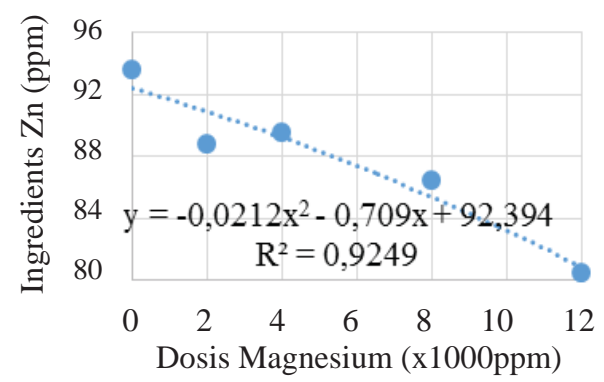

Figure $1 \mathrm{f}$

Figure 1. Administration of magnesium foliar fertilizer with minerals content of M. bracteata (1a: Phosphor, 1b: Calcium, 1c: Magnesium, 1d: Kalium, 1e: Natrium, 1f: Zink)

natrium and CBL 1 \& CBL-9 for kalium. When the natrium content is increase, $\mathrm{CBL}-10$ will give signal to plasm membrane to absorb natrium content excess and it is stored in vacuola and the CIPKs24 will give signal to decrease natrium content in the plasm membrane. When kalium concentration in cell membrane is decrease, censor CLB-1 \& CLB 9 will give signal to plasm membrane to increase absorption of kalium in the cell membrane (Gao et al. 2015a). Vacuola was an organ which has several functions, such as in saving nutrition and metabolic, degradation of protein, and plant defense (Gao et al. 2015b). 
Table 4. Macro mineral absorption of $M$. bracteata leaves as effext of magnesium foliar fertilizer application in different level

\begin{tabular}{|c|c|c|c|c|c|c|}
\hline Level of magnesium (ppm) & $\mathrm{P}$ & $\mathrm{Ca}$ & $\mathrm{Mg}$ & K & $\mathrm{Na}$ & $\mathrm{Zn}$ \\
\hline & \multicolumn{6}{|c|}{ 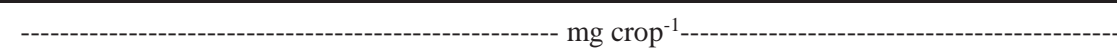 } \\
\hline 0 & $16.8 \pm 8.7$ & $182.8 \pm 92.8$ & $121.8 \pm 53.9$ & $1128.8 \pm 468.7$ & $1.8 \pm 0.9$ & $0.9 \pm 0.4$ \\
\hline 2000 & $11.1 \pm 7.6$ & $159.9 \pm 145.9$ & $171.5 \pm 143.4$ & $869.0 \pm 743.9$ & $1.9 \pm 1.4$ & $0.7 \pm 0.6$ \\
\hline 4000 & $20.0 \pm 11.6$ & $136.1 \pm 122.8$ & $218.1 \pm 133.8$ & $931.3 \pm 477.4$ & $2.4 \pm 0.9$ & $1.0 \pm 0.5$ \\
\hline 8000 & $13.0 \pm 2.9$ & $122.8 \pm 74.5$ & $235.1 \pm 83.7$ & $752.3 \pm 289.6$ & $2.0 \pm 0.8$ & $0.7 \pm 0.3$ \\
\hline 12000 & $9.5 \pm 4.3$ & $73.7 \pm 15.4$ & $162.5 \pm 32.5$ & $533.7 \pm 176.1$ & $1.4 \pm 0.2$ & $0.5 \pm 0.2$ \\
\hline
\end{tabular}

Table 5. Chlorophyll level of $M$. bracteata as effect of magnesium foliar fertilizer application in different level

\begin{tabular}{|c|c|c|c|c|}
\hline Level of magnesium (ppm) & Chlorophyll A & Chlorophyll B & Antocianine & Caroten \\
\hline & & . & & 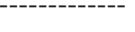 \\
\hline 0 & $0.53 \pm 0.14$ & $0.22 \pm 0.06$ & $0.02 \pm 0.01$ & $0.16 \pm 0.04$ \\
\hline 2000 & $0.47 \pm 0.09$ & $0.20 \pm 0.04$ & $0.03 \pm 0.01$ & $0.14 \pm 0.02$ \\
\hline 4000 & $0.48 \pm 0.10$ & $0.21 \pm 0.05$ & $0.03 \pm 0.01$ & $0.14 \pm 0.03$ \\
\hline 8000 & $0.58 \pm 0.06$ & $0.25 \pm 0.02$ & $0.02 \pm 0.00$ & $0.18 \pm 0.02$ \\
\hline 12000 & $0.56 \pm 0.04$ & $0.24 \pm 0.03$ & $0.03 \pm 0.01$ & $0.17 \pm 0.01$ \\
\hline
\end{tabular}

Mineral level of $M$. bracteata was including to high grade refered to McDonald et al (2010) compared with mineral level of grass in temperate area, even mineral level of kalium and phosphor of Murdannia bracteta was lower than in Indigofera sp. (Herdiawan 2013). High mineral level in this crop is potential as an organic mineral source for slow release animal.

Result of analysis of variance showed that addition of magnesium did not significantly $(\mathrm{P}>0.05)$ affect absorbtion of mineral. This showed that the amount of mineral absorbed in different level showed the same result. It was suspected due to nutrient in the soil meets nutrient requirement for optimal grow. This mineral absorbtion also showed that minerals used for metabolism in crop were enough to fulfill vegetative and generative growth.

Chlorophyll is green substance which closely related to absorption of light and process of photosynthesis. Chlorophyll is divided into chlorophyll A (C55H72O5N4Mg) with dark green color and chlorophyll B (C55H70O5N4Mg) with light green color (Wihermanto \& Handayani 2011). Magnesium is a core mineral in the chlorophyll. Magnesium atom, which was photosynthesis process determinant, was very decisiving productivity process of crops (Gransee \& Fuhrs 2013). Addition of magnesium foliar fertilizer in different level did not significantly $(\mathrm{P}>0.05)$ affect content of chlorophyll of the M. bracteata.

This is suspected because of forming of chlorophyll of $M$. bracteata was optimal, so that when the magnesium foliar fertilizer was added up to 12000 ppm, it did not give significant affect. Besides, the amount of magnesium absorption in every crop did not show significant affect, so that the magnesium added will directly be stored in vacuola. The amount of magnesium absorbed did not increase, therefore chlorophyll level also did not increase indirectly. Magnesium used by crops for photosyntesis process was about $20 \%$ of total magnesium in the crop, whereas the rest of $80 \%$ was left mobile in the crop (Marschner 2012). Addition of high magnesium did not cause toxivity to the $M$. bracteata.

\section{CONCLUSION}

Addition of magnesium foliar fertilizer up to 12000 ppm increased magnesium content and did not give negative effect to growth, productiovity, and quality of crop. Increasing of magnesium level affected decrase of several minerals content (Ca, C, and Zn) in crop.

\section{REFERENCES}

Aghtape AA, Ahmad G, Alireza S, Baratali S, Mohammadreza A, Abolfazi T. 2011. Effect of irrigation with wastewater and foliar fertilizer application on some forage characteristic of foxtail millet (Setaria italica). J Plant Physiol Biochemist. 3:34-42. 
Rahmawati et al. Production and quality of Murdannia bracteata biomass as impact of magnesium foliar fertilizer

Barker AV, Eaton TE. 2015. Zink. In: Handbook of Plant Nutrition 2nd ed. Barker AV, Pilbeam DJ, editors. New York (USA): Taylor \& Francis Group.

Chalimah S, Sulaiman W. 2015. Uji potensi hasil produksi pupuk organik granil limbah biogas terhadap pertumbuhan tanaman tomat (Solanum lycopersium). University Research Colloguium 2015 Universitas Muhammadiyah Surakarta. hlm. 186-194.

Fitriyatno, Suparti, Sofyan A. 2012. Uji pupuk organik cair dari limbah pasar terhadap pertumbuhan tanaman selada (Lactuca sativa L.) dengan media hidroponik. Seminar Nasional IX Pendidikan Biologi FKIP UNS. hlm. 635641.

Gerendàs J, Führs H. 2013. The significance of magnesium for crop quality. Plant Soil. 368:101-128.

Gransee A, Fuhrs H. 2013. Magnesium mobility in soils as a challenge for soil and plant analysis, magnesium fertilization and root uptake under adverse growth condition. Plant Soil. 368:5-21.

Gao C, Zhao Q, Jiang L. 2015a. Vacuoles protect plants from high magnesium stress. Proc Natl Acad Sci USA 112:2931-2932.

Gao C, Zhuang X, Cui Y, Fu X, He Y, Zhao Q, Zeng Y, Shen J, Lio M, Juang L. 2015b. Dual roles of an Arabidopsis ESCRT component FREE 1 in regulating vacuolar protein transport and autophagic degradation. Proc Natl Acad USA. 112:1886-1891.

Grzebisz W. 2015. Magnesium. In: Handbook of Plant Nutrition 2nd ed. Barker AV, Pilbeam DJ, editors. New York (USA): Taylor \& Francis Group.

Hanadyo R, Hadiastono T, Martosudiro M. 2013. Pengaruh pemberian pupuk daun cair terhadap intensitas serangan tobacco mosaic virus (TMV), pertumbuhan, dan produktivitas tanaman tembakau (Nicotina tabacum L.). JHPT. 1:28-35.

Herdiawan I. 2013. Pertumbuhan tanaman pakan ternak leguminosa pohon Indigofera zollingeriana pada berbagai taraf perlakuan cekaman kekeringan. JITV. 18:258-264.

Matjik AA, Sumertajaya M. 2006. Perancangan percobaan dengan aplikasi SAS dan Minitab. Edisi ke-2. Bogor (Indones): IPB Press.

Marschner H. 2012. Mineral nutrition of higher plants. 3rd ed. San Diego (USA). Academic, Elsevier.

Mengel K. 2007. Pottasium. In: Handbook of Plant Nutrition. Barker AV, Pilbeam DJ, editors. New York (USA): Taylor \& Francis Group.
Merhaut DJ. 2007. Magnesium. In: Handbook of Plant Nutrition. Barker AV, Pilbeam DJ, editors. New York (USA): Taylor \& Francis Group.

McDonald P, Edwards RA, Greenhalgh JFD, Morgan CA. 2010. Animal nutrition. Edisi ke-7. New York (USA): Longman Scientific and Technical.

Portu J, Gonzalez-Arenzana L, Hermosin-Gutierrez I, Santamaria P, Garde-Cerdan T. 2015. Phenylalanine and urea foliar applications to grapevine: effect on wine phenolic content. Food Chemist. 180:55-63.

Rais H. 2015. Karakteristik fermentasi rumen dan sintesis protein mikroba In-vitro dengan penggunaan Murdannia bracteata sebagai hijauan fungsional (Tesis). [Bogor (Indones)]: Institut Pertanian Bogor.

Rahmawati T. 2014. Respon tanaman Murdannia bracteata terhadap aolikasi pupuk organik dan naungan (Skripsi). [Bogor (Indones)]: Institut Pertanian Bogor.

Reitz LL, Smith WH, Plumlee MP. 1960. A simple, wet oxidation procedure for biological materials. Indiana (USA): Purdue University.

Salama ASM, Omima, El-Sayed M, Abdel-Hameed AA. 2014. Effect of magnesium fertilizer sources and rates on yield and fruit quality of Date Palm cv. hayany under Ras-Sudr condition. Res J Agric Biol Sci. 10:118-126.

Sims DA, Gamon JA. 2002. Relationships between leaf pigment content and spectral reflectance across a wide range of species, leaf structures and development stages. Remote Sens Environ. 81:337-354.

Supartha INY, Wijana G, Adnyana GM. 2012. Aplikasi jenis pupuk organik pada tanaman padi sistem pertanian organik. J Agrotek Tropika. 1:98-106.

Tang RJ, Zhao FG, Garcia VJ, Kleist TJ, Yang L, Zhang HX, Luan S. 2015. Tonoplast CBL CIPK calcium signaling network regulates magnesium homeostasis in Arabidopsis. Proc Natl Acad Sci USA. 112:3134-3139.

Utami Y. 2015. Produktivitas dan kualitas hijauan Indigofera zollingriana yang diinokulasi fungi mikoriza arvuskula dengan berbagai level boron (Tesis). [Bogor (Indones)]: Institut Pertanian Bogor.

Wang GJ, Chen SM, Chen WC, Chang YM, Lee TH. 2007. Selective inducible nitric oxide synthase suppression by new bracteanolides from Murdannia bracteata. J Ethnopharmacol. 112:221-227.

Wihermanto, Handayani T. 2011. Pengaruh naungan paranet terhadap sifat toleransi tanaman kecapi (Sandoricum koetjape (Burm.f.) Merr. Seminar Nasional HUT Kebun Raya Cibodas ke-19. hlm. 506-509. 